\title{
Propozycja usprawnienia metodyki pomiarów dopływów wód podziemnych do wyrobisk w kopalniach LGOM na przykladzie OG Polkowice
}

\author{
Marek Błachowicz ${ }^{1}$
}

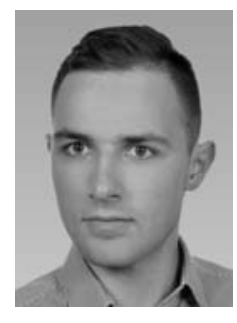

The proposal of methodology of measurements and estimation of groundwater inflow into underground workings of LGOM mines exemplified by the Polkowice mining area. Prz. Geol., 66: 510-518; doi: 10.7306/2018.5.

A b s tra ct. This paper presents an analysis of the groundwater inflow into the Polkowice mining area. It is a mining area where the highest inflow into the mine from the whole Legnica-Glogów Copper District can be observed. In the multi-aquifer formation system, which occurs in the study area, a significant role is played by: Paleogene and Neogene, Triassic and Permian aquifers. The principal objective was to determine the discharging groundwater resources in deep aquifers in relation to the current hydrogeological conditions observed in the mine. The results helped to describe problems and possibilities of high frequency measurements in mine workings and to give some clues to the improvement of measurement methodology. This research was based on direct measurements, analysis of collecting data, and a comparison with existing data regarding the inflow into the mine workings.

Keywords: underground mine drainage, Legnica-Głogów Copper District, Polkowice-Sieroszowice Mine, measurement methodology

Kopalnie Legnicko-Głogowskiego Okręgu Miedziowego (LGOM) na Dolnym Śląsku od przeszło 50 lat prowadzą podziemną eksploatację rud miedzi w utworach permu na monoklinie przedsudeckiej. Jednym z kluczowych aspektów, wpływających na techniczno-organizacyjne możliwości tej eksploatacji, są warunki hydrogeologiczne, jakie ukształtowały się w czasie prac górniczych, dlatego wyniki badań $\mathrm{w}$ tej dziedzinie są kluczowe dla robót udostępniających złoże i gospodarki wodnej kopalń.

Badanie tak złożonego zagadnienia, jakim jest drenaż podziemnej kopalni, wymaga równoległej analizy wielu danych. Obserwacje hydrogeologiczne, dotyczące m.in. ilości odprowadzonych wód i dopływów do złoża, są prowadzone w kopalniach LGOM co miesiąc, a stan zwierciadła wód podziemnych w poszczególnych poziomach wodonośnych sprawdza się co kwartał. Największe dopływy wód podziemnych do wyrobisk górniczych obserwuje się obecnie na terenie LGOM w obszarach złóż Polkowice oraz Lubin-Małomice (Becker i in., 2007).

Celem badań było sprawdzenie, czy po zaprojektowaniu sieci stanowisk przystosowanych do prowadzenia pomiarów wielkości dopływów z dużą częstotliwością próbkowania uzyska się nowe, interesujące dane, na podstawie których można będzie lepiej opisać dynamikę dopływów wód do obszaru górniczego Polkowice i poprawić interpretację zjawisk hydrogeologicznych na potrzeby współczesnej i przyszłej działalności górniczej oraz zagrożeń wodnych w kopalniach LGOM.

\section{WARUNKI GEOLOGICZNE}

Badania prowadzono na obszarze złoża miedzi Polkowice, w południowo-zachodniej części monokliny przedsudeckiej, tuż przy granicy z blokiem dolnośląskim (ryc. 1). W podłożu występują tu skały magmowe i metamorficzne wieku proterozoicznego, przykryte skałami osadowymi karbonu. Niezgodnie zalegają na nich paleozoiczno-mezozoiczne utwory permsko-triasowe (Kłapciński, 1971; Kłapciński, Peryt, 2007).
W skałach wieku permskiego stwierdzono występowanie strefy okruszcowanej, związanej ze stropowymi częściami czerwonego spagowca oraz spagowymi utworami cechsztynu (Wyżykowski, 1958, 1971). Do utworów triasu na badanym obszarze zalicza się poziom dolnego pstrego piaskowca (Kwaśny, Kalisz, 2011). W profilu obszaru badań wyróżnia się także osadowe serie kenozoiku, należące do paleogenu i neogenu. Zalegają one niezgodnie na utworach permsko-triasowych, tworząc miąższą pokrywę (do kilkuset metrów) luźnych utworów piaszczysto-żwirowych z mułkami, iłami i licznymi horyzontami węgla brunatnego (Dyjor, 1978; Bocheńska, 2003).

Do najmłodszych skał wydzielanych na badanym obszarze należą luźne osady czwartorzędowe, zaliczane do plejstocenu i holocenu, o miąższości od kilku do kilkudziesięciu metrów. Utwory czwartorzędowe tworzą głównie gliny moren czołowych i piaszczyste osady sandrowe, natomiast osady holoceńskie występują jedynie w dolinach rzecznych i obniżeniach morfologicznych (Bocheńska, 2003; Kłapciński, Peryt, 2007).

\section{WARUNKI HYDROGEOLOGICZNE}

W granicach LGOM wyróżnia się trzy główne kompleksy wodonośne: skał krystalicznego podłoża, permsko-triasowy oraz kenozoiczny. Najstarszy kompleks gromadzi (w części stropowej) wyłącznie wody szczelinowe i charakteryzuje się znikomym udziałem w wielkości zawodnienia kopalń (Bocheńska, 2003).

Na kompleks permsko-triasowy składają się zawodnione utwory piaskowców czerwonego spagowca (stanowiące spag złoża), cechsztyńskich wapieni i dolomitów oraz utwory pstrego piaskowca. Permsko-triasowe piętro wodonośne cechuje się szczelinowo-porowym przepływem wody.

Kenozoiczny kompleks wodonośny występuje w utworach paleogeńsko-neogeńskich oraz czwartorzędowych. Tworzy go kilkadziesiąt warstw piaszczysto-żwirowych o miąższości od kilku do kilkunastu metrów (z intergranularnym przepływem wód), rozdzielonych przez kilkana-

\footnotetext{
${ }^{1}$ Instytut Nauk Geologicznych, Uniwersytet Wrocławski, pl. M. Borna 9, 50-204 Wrocław; marek.blachowicz@uwr.edu.pl.
} 
ście warstw węgla brunatnego oraz iłowcowe warstwy izolujące. W piętrze czwartorzędowym wyróżnia się poziomy wodonośne holocenu i plejstocenu, które nie mają znaczenia dla działalności górniczej prowadzonej przez kopalnie podziemne.

Decydujący wpływ na wielkość zawodnienia wyrobisk mają podplejstoceńskie poziomy wodonośne, zwłaszcza permsko-triasowe poziomy złożowe i przyzłożowe. Obraz warunków hydrogeologicznych uzupełniają liczne warstwy izolujące i utrudniające swobodny przepływ wód pomiędzy poziomami różnych pięter wodonośnych (Bocheńska, 2003; Becker i in., 2007; Staśko i in., 2002).

Już pod koniec lat 60 . XX w. zwrócono uwagę na nierównomierne zawodnienie przyzłożowych poziomów wodonośnych na obszarze LGOM (Sztelak, 1968). Zaproponowano wówczas podział okręgu na rejon północny i południowy wg kryterium zawodnienia cechsztyńskich wapieni i dolomitów poziomu Ca1, gdzie w południowej części obserwuje się największe dopływy do wyrobisk względem obszaru północnego (ryc. 1 i 2). W późniejszych latach warunki hydrodynamiczne pięter i poziomów wodonośnych na obszarze LGOM szczegółowo opisali m.in.: Banaszak i Banaś (1996, 2007), Bocheńska (1988, 2003), Bocheńska i in. (2000), Bocheńska i Kalisz (2001), Becker i in. (2006) oraz Staśko i in. (2012).

\section{SYSTEM ODWADNIANIA KOPALNI POLKOWICE-SIEROSZOWICE I DRENAŻ GÓROTWORU}

W zestawieniach wielkości dopływu wód podziemnych do obszaru górniczego Polkowice $\left(74,21 \mathrm{~km}^{2}\right)$ uwzględnia się podział złoża na zlewnie podziemne (technologiczne): Polkowice Zachód (PZ), Polkowice Główne (PG) oraz Polkowice Wschód (PW). Podział ten jest zdeterminowany ukształtowaniem powierzchni spagu wyrobisk, które definiuje kierunek spływu wód. Transport wód dołowych odbywa się głównie grawitacyjnie poprzez wyeksploatowane obszary złoża, chodnikami wodnymi oraz w mniejszym stopniu rurociagami (Stochel, Chudy, 2014).

System odwadniania złoża Polkowice polega na współdziałaniu pompowni głównego odwadniania (zlokalizowanej przy szybach P-I, P-II), pompowni rejonowej Polkowice Zachód (zlokalizowanej przy szybach P-V i P-VI), osadników, sieci rurociagów i chodników wodnych (ryc. 2).

Wody dołowe $\mathrm{z}$ obszaru górniczego Polkowice są $\mathrm{w}$ większości kierowane do pompowni głównego odwadniania w rejonie Polkowice Główne, skąd są odprowadzane przez zręby szybów za pomocą 3 rurociągów tłocznych do Zakładu Wzbogacania Rud KGHM Polska Miedź S.A. w Polkowicach, gdzie są wykorzystywane w procesach technologicznych przeróbki kopalin. Pompownia rejonowa Polkowice Zachód odpowiada za odprowadzenie części wód dołowych ze złoża Sieroszowice oraz niewielkiej części wód ze złóż Polkowice i Radwanice. Wody te są przekazywane do chodnika wodnego i poprzez kanał pomiarowy trafiają do pompowni głównego odwadniania.

Gospodarka wodna zespołu kopalń LGOM zakłada jak największe wtórne wykorzystanie wód pochodzących z górotworu. Wykorzystuje się je do przepłuczki w procesach wiercenia otworów strzałowych i kotwowych, do mycia maszyn i pojazdów transportowych oraz w instalacji przeciwpożarowej. Wody te, jako wody technologiczne

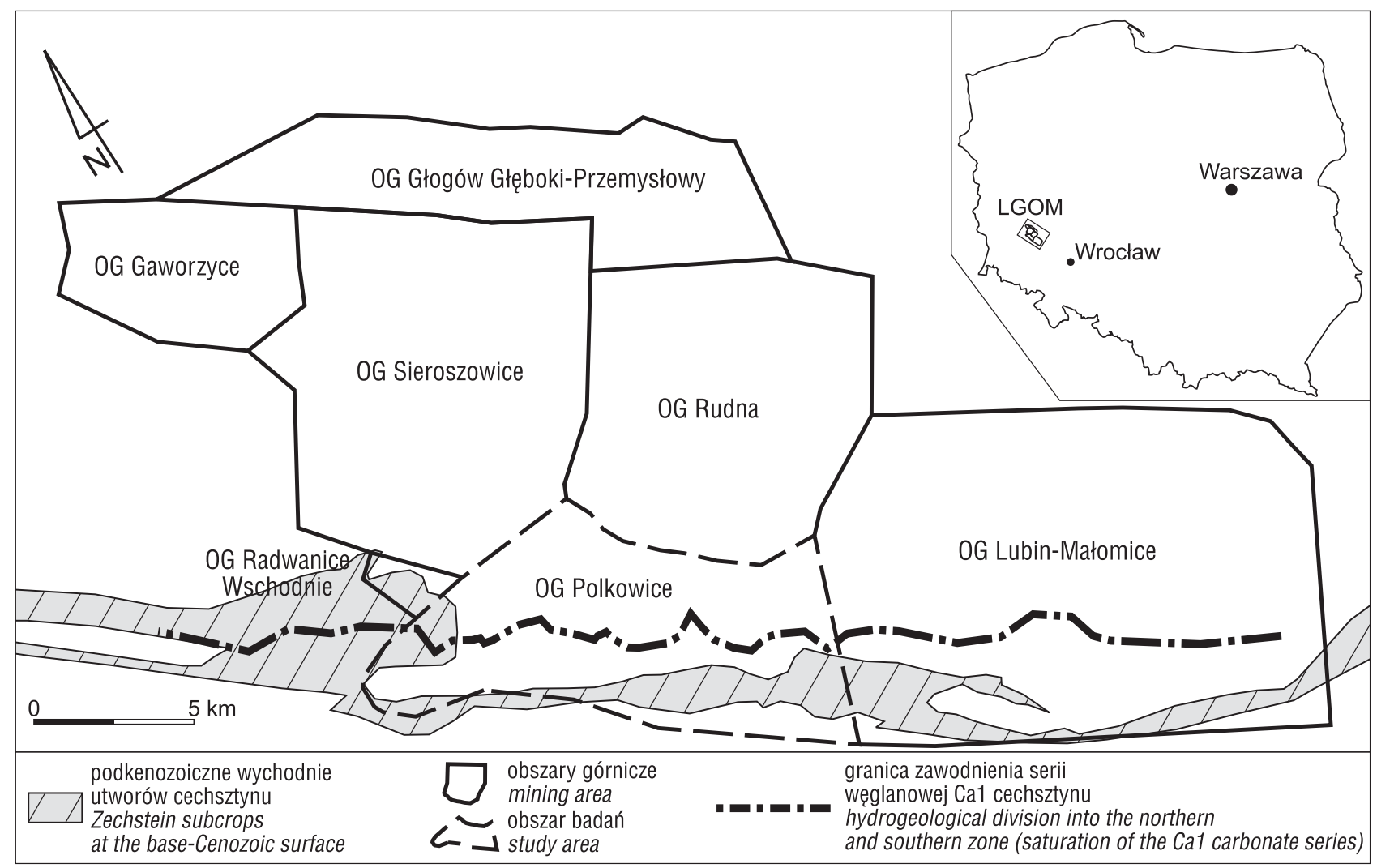

Ryc. 1. Lokalizacja terenu badań na tle obszarów górniczych Legnicko-Głogowskiego Okręgu Miedziowego (na podstawie Chudy i in., 2017 - zmieniona)

Fig. 1. Study area location against the background of mining areas of the Lubin-Głogów Copper Ore District (based on Chudy et al., 2017 - changed) 


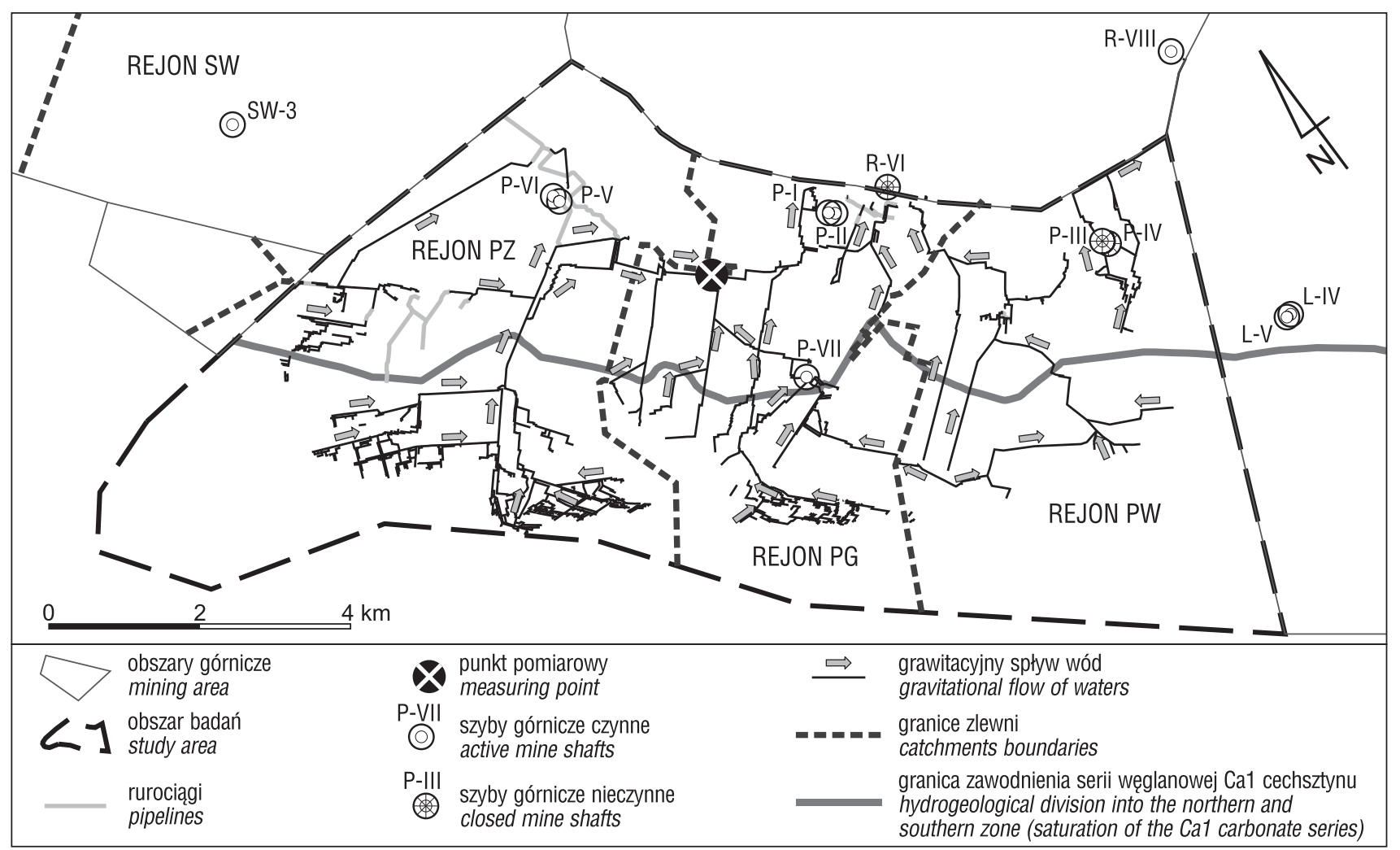

Ryc. 2. Obszar badań z podziałem na rejony (zlewnie) z lokalizacją punktu pomiarowego

Fig. 2. Study area divided into divisions (catchments) with location of measuring point

Tab. 1. Średni dopływ wód do obszaru górniczego Polkowice w latach 2000-2016, z uwzględnieniem podziału na zlewnie (na podstawie Stochel, Chudy, 2014; Rejestr, 2000-2016)

Table 1. Average annual total inflow into the Polkowice mining area during 2000-2016, divided into catchments (based on Stochel, Chudy, 2014; Rejestr, 2000-2016)

\begin{tabular}{|c|c|c|c|c|c|c|c|c|c|c|}
\hline \multirow[b]{3}{*}{$\begin{array}{l}\text { Rok } \\
\text { Year }\end{array}$} & \multicolumn{10}{|c|}{$\begin{array}{l}\text { Dopływ wód do obszaru górniczego Polkowice }\left[\mathrm{m}^{3} / \mathrm{min}\right] \\
\text { Inflow into Polkowice mining area }\left[\mathrm{m}^{3} / \mathrm{min}\right]\end{array}$} \\
\hline & \multicolumn{3}{|c|}{$\begin{array}{l}\text { Polkowice Wschód } \\
\text { East Polkowice }\end{array}$} & \multicolumn{3}{|c|}{$\begin{array}{l}\text { Polkowice Glówne } \\
\text { Main Polkowice }\end{array}$} & \multicolumn{3}{|c|}{$\begin{array}{l}\text { Polkowice Zachód } \\
\text { West Polkowice }\end{array}$} & \multirow[b]{2}{*}{$\begin{array}{c}\text { Doplyw } \\
\text { calkowity } \\
\text { Total inflow }\end{array}$} \\
\hline & $\begin{array}{c}\text { Otwory } \\
\text { badawcze } \\
\text { i drenażowe } \\
\text { Test and } \\
\text { drainage } \\
\text { boreholes }\end{array}$ & \begin{tabular}{|c|} 
Wycieki \\
ze szczelin \\
i pól \\
zawalowych \\
Seeps from \\
fractures \\
and collapse \\
fields \\
\end{tabular} & \begin{tabular}{|c|} 
Doplywy \\
do wyrobisk \\
poziomych \\
Inflows into \\
horizontal \\
mine \\
workings
\end{tabular} & $\begin{array}{c}\text { Otwory } \\
\text { badawcze } \\
\text { i drenażowe } \\
\text { Test and } \\
\text { drainage } \\
\text { boreholes }\end{array}$ & $\begin{array}{c}\text { Wycieki } \\
\text { ze szczelin } \\
\text { i pól } \\
\text { zawalowych } \\
\text { Seeps from } \\
\text { fractures } \\
\text { and collapse } \\
\text { fields } \\
\end{array}$ & $\begin{array}{c}\text { Doplywy } \\
\text { do wyrobisk } \\
\text { poziomych } \\
\text { Inflows into } \\
\text { horizontal } \\
\text { mine } \\
\text { workings }\end{array}$ & \begin{tabular}{|c|} 
Otwory \\
badawcze \\
i drenażowe \\
Test and \\
drainage \\
boreholes
\end{tabular} & \begin{tabular}{|c|} 
Wycieki \\
ze szczelin \\
i pól \\
zawalowych \\
Seeps from \\
fractures \\
and collapse \\
fields \\
\end{tabular} & \begin{tabular}{|} 
Doplywy \\
do wyrobisk \\
poziomych \\
Inflows into \\
horizontal \\
mine \\
workings
\end{tabular} & \\
\hline 2000 & 0,020 & 1,570 & 1,590 & 2,758 & 0,325 & 3,082 & 19,980 & 5,775 & 25,755 & 30,427 \\
\hline 2001 & 0,215 & 1,203 & 1,353 & 3,837 & 0,452 & 4,289 & 19,679 & 2,754 & 22,434 & 28,076 \\
\hline 2002 & 1,123 & 0,509 & 1,632 & 3,561 & 0,439 & 4,000 & 16,926 & 3,868 & 20,793 & 26,425 \\
\hline 2004 & 0 & 1,661 & 1,661 & 4,052 & 0,348 & 4,400 & 15,307 & 4,106 & 19,414 & 25,475 \\
\hline 2006 & 0 & 1,068 & 1,068 & 4,519 & 0,474 & 4,993 & 14,051 & 4,092 & 18,143 & 24,204 \\
\hline 2007 & 0 & 1,375 & 1,375 & 4,730 & 0,491 & 5,221 & 12,043 & 5,905 & 17,948 & 24,544 \\
\hline 2008 & 0 & 1,082 & 1,082 & 4,008 & 0,509 & 4,517 & 12,050 & 4,827 & 16,877 & 22,476 \\
\hline 2009 & 0 & 1,043 & 1,043 & 3,410 & 0,524 & 3,934 & 15,332 & 4,226 & 19,558 & 24,535 \\
\hline 2010 & 0 & 0,817 & 0,817 & 3,996 & 0,347 & 4,347 & 16,184 & 9,855 & 26,039 & 31,203 \\
\hline 2011 & 0 & 0,839 & 0,839 & 3,878 & 0,337 & 4,215 & 13,888 & 8,383 & 22,726 & 27,780 \\
\hline 2012 & 0 & 0,851 & 0,851 & 0,860 & 2,438 & 3,298 & 12,308 & 10,800 & 23,108 & 27,256 \\
\hline 2013 & 0 & 0,885 & 0,885 & 0,930 & 2,230 & 3,160 & 11,601 & 13,180 & 24,781 & 28,825 \\
\hline 2014 & 0 & 0,820 & 0,820 & 0,538 & 2,0520 & 2,590 & 13,898 & 10,460 & 24,358 & 27,768 \\
\hline 2015 & 0 & 0,849 & 0,849 & 0,295 & 2,278 & 2,573 & 15,556 & 7,230 & 22,786 & 26,208 \\
\hline 2016 & 0 & 1,040 & 1,040 & 0,268 & 2,481 & 2,749 & 13,559 & 6,180 & 19,739 & 23,527 \\
\hline
\end{tabular}


z OG Polkowice, są kierowane do OG Sieroszowice w ilości nieco ponad $1 \mathrm{~m}^{3} / \mathrm{min}\left(1,11 \mathrm{~m}^{3} / \mathrm{min}\right.$ w $2016 \mathrm{r}$. $)$ i w ogólnym bilansie wymiana wód między tymi obszarami górniczymi wypada na korzyść OG Polkowice (+ 0,41 $\mathrm{m}^{3} / \mathrm{min}$ w $2016 \mathrm{r}$.).

Do 2014 r. wody dołowe z obszaru badań były przekazywane jako technologiczne również do OG Rudna. Obecnie do systemu odwodnienia Kopalni Rudna trafia niewielka ilość dopływu z rejonów PG i PW $\left(0,88 \mathrm{~m}^{3} / \mathrm{min}\right.$ w 2016 r.).

Dopływ wód do obszaru górniczego Polkowice można podzielić na bezpośredni i pośredni. Dopływ bezpośredni jest kształtowany przez wycieki ze szczelin i pól zawałowych, natomiast za dopływ pośredni odpowiadaja otwory badawcze i drenażowe, które są wykonywane w czasie robót udostępniających złoże, poprzedzających główny front eksploatacji. Ze względów technicznych dokładniej można określić wielkość dopływów pośrednich do złoża, dzięki czemu uzyskuje się możliwość lepszego monitorowania wpływu eksploatacji na zawodnienie wyrobisk oraz skutków zaprzestania prac wydobywczych.

Zgodnie z Rozporządzeniem Ministra Energii z dnia 23 listopada 2016 r. w sprawie szczegółowych wymagań dotyczących prowadzenia ruchu podziemnych zakładów górniczych oraz zgodnie $\mathrm{z}$ wcześniej obowiązującym Rozporządzeniem Ministra Gospodarki z dnia 28 czerwca 2002 r. w sprawie bezpieczeństwa i higieny pracy, prowadzenia ruchu oraz specjalistycznego zabezpieczenia przeciwpożarowego $\mathrm{w}$ podziemnych zakładach górniczych (z późniejszymi zmianami) pomiary dopływu wód do wyrobisk górniczych w kopalniach LGOM wykonuje się nie rzadziej niż 2 razy w roku. W latach 1980-2010 pomiary te były wykonywane cztery razy do roku (Stochel, Chudy, 2014).

W latach 2010-2016 największy udział w dopływie wód do obszaru górniczego Polkowice miały wody pochodzące ze zlewni technologicznej Polkowice Zachód (tab. 1, ryc. 3). $Z$ tego rejonu pochodziło ponad $80 \%$ wód, których strumień w przeważającej mierze kształtowały dopływy pośrednie z otworów badawczych i drenażowych. Taki reżim wodny wynikał z koncentracji prac udostępniających złoże miedzi w rejonie zlewni PZ - w obszarze południowym względem rejonizacji hydrogeologicznej złoża - i uzasadniał wybór miejsca instalacji aparatury pomiarowej.

W obszarze zlewni PW, w związku z wygaszaniem robót udostępniających nowe partie złoża, już w 2002 r. ustał dopływ wód z otworów badawczych i drenażowych. Cały dopływ wód podziemnych jest w tym rejonie kształtowany przez wycieki ze szczelin i pól zawałowych. Od 1997 r. rejon PZ odpowiadał za więcej niż 70\% całkowitego dopływu wód do złoża (ryc. 3), a od 2014 r. za niemal $88 \%\left(24,358 \mathrm{~m}^{3} / \mathrm{min}\right)$. W $2016 \mathrm{r}$. sumaryczny dopływ wód do rejonu PZ spadł poniżej $20 \mathrm{~m}^{3} / \mathrm{min}$ (po raz pierwszy od 2007 r.) i wyniósł $19,74 \mathrm{~m}^{3} / \mathrm{min}$, co stanowi $83,9 \%$ wszystkich dopływów (tab. 1 ).

\section{METODYKA BADAŃ}

Ze względu na możliwości techniczne oraz dominujący udział w generowaniu dopływu wód do obszaru górniczego Polkowice (ryc. 3) do przeprowadzenia pomiarów wybrano zlewnię rejonu górniczego Polkowice Zachód.

W kopalniach podziemnych do określania natężenia przepływu wód w wyrobiskach górniczych stosuje się zazwyczaj metody pomiarowe polegające na przelewach oraz metody pływakowe (Rogoż, 2004). Z uwagi na to, że w wyrobiskach górniczych woda płynie zazwyczaj po spagu chodników i tworząca się w nich struga charakteryzuje się małą głębokością oraz dużą szerokością, zastosowanie innych metod pomiaru jest utrudnione.

Pomiary natężenia dopływu wód z obszaru górniczego Polkowice Zachód prowadzono z wysoką częstotliwością, za pomocą automatycznego, elektronicznego limnimetru pojemnościowego firmy Odyssey. Urządzenie to zamontowano w specjalnie przystosowanym do tego typu badań kanale pomiarowym, który przechwytuje nie tylko wszystkie wody dołowe ze zlewni Polkowice Zachód, ale również zrzuty wód z rejonu Sieroszowic (ryc. 2). Jest to betonowe koryto długości ok. $10 \mathrm{~m}$, o stałym, prostokątnym przekroju (ryc. 4). W celu ograniczenia negatywnego wpływu zbyt dużych wahań poziomu wody, które występują w kanale i mogłyby zniekształcić wyniki pomiarów, limnimetr umieszczono w metalowej rurze zainstalowanej $\mathrm{w}$ jednym $\mathrm{z}$ boków kanału. Urząadzenie rejestrujące wykonywało pomiar z częstotliwością co 30 minut przez prawie pół roku.

Działanie limnimetru polega na ciagłym pomiarze pojemności elektrycznej przewodu zanurzonego w wodzie, która zmienia się wraz ze zmianami wysokości zwierciadła wody. Rejestrator mierzy zatem pojemność elektryczną przewodu niezwilżonego w odniesieniu do części przewodu, która jest zanurzona (uziemiona). Dokładność pomiarów limnigrafu wynosi $0,8 \mathrm{~mm}$ i jest zależna od prawidłowego wykonania kalibracji.

Pierwotnie zakładano, że pomiary będą prowadzone przez cały 2016 r., a uzyskane wyniki można będzie skonfrontować z danymi o ilości wody odprowadzanej w ciągu roku przez Kopalnię Polkowice-Sieroszowice. Niestety, z przyczyn technicznych, niezależnych od autora, zainsta-

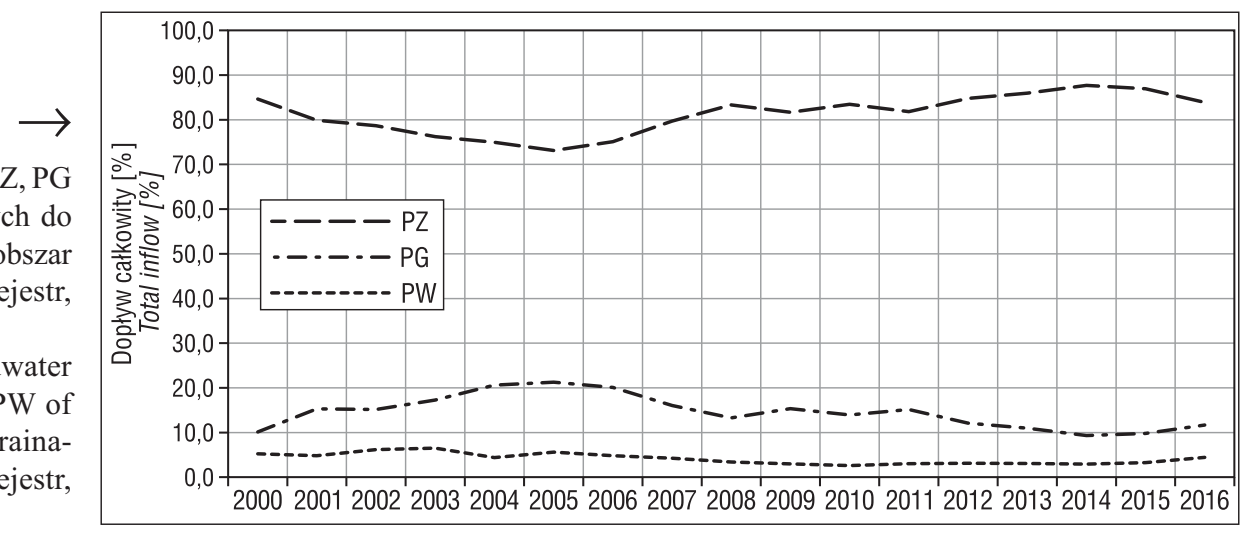




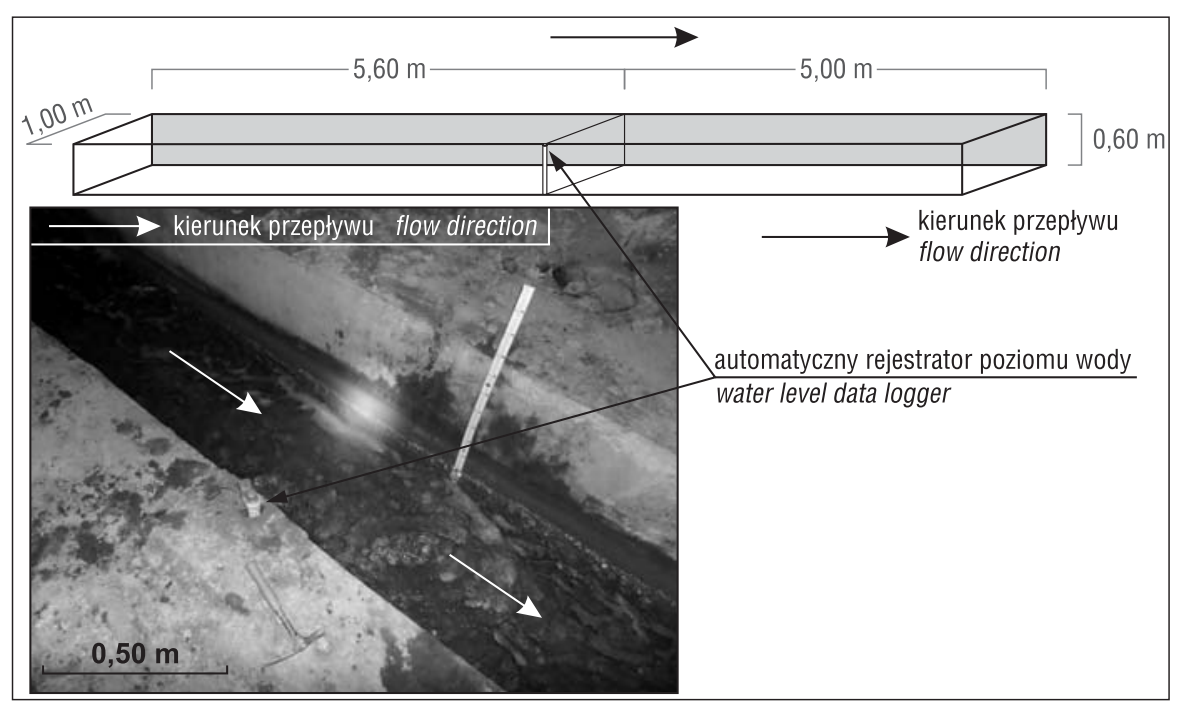

\section{$\leftarrow$}

Ryc. 4. Schemat kanału pomiarowego ujmującego wody ze zlewni Polkowice Zachód (PZ) z lokalizacją automatycznego rejestratora poziomu wody

Fig. 4. Scheme of the measuring channel in the Polkowice Zachód Division (Catchment) (PZ) with location of the water level data logger

\section{$\longrightarrow$}

Ryc. 5. Krzywa stan-przepływ wyznaczona dla kanału pomiarowego

Fig. 5. Curve stage-flow fixed to the measuring channel

lowana aparatura dokonywała pomiarów jedynie od stycznia do połowy maja 2016 r. Później pomiary nie były kontynuowane, a dane uzyskane po 20 maja (po wymianie limnimetru) są, według autora, niewiarygodne. Ponadto w pierwszej połowie stycznia 2016 r. na terenie LGOM wykonywano prace mające na celu przechwycenie całości wód dołowych z rejonu Polkowic (których transport odbywał się awaryjnymi chodnikami wodnymi) i przekierowanie ich do kanału pomiarowego. $\mathrm{Z}$ tego powodu w analizie wzięto pod uwagę wyniki pomiarów stanu wód w kanale mierzone od 20 stycznia do 19 maja 2016 r., a zatem okres pomiarowy obją tylko 4 miesiące.

Przepływ wód w kanale określono na podstawie pomiaru prędkości przepływu strumienia wód wykonanego za pomocą młynka hydrometrycznego (wirnikowego) z elektronicznym panelem sterującym (He-Ga1) w odniesieniu do powierzchni przekroju koryta (Bajkiewicz-Grabowska $\mathrm{i}$ in., 1993). Po skorelowaniu stanów wód w kanale z wynikami pomiarów prędkości ich przepływu wyznaczono empiryczną krzywą stan-przepływ (ryc. 5).

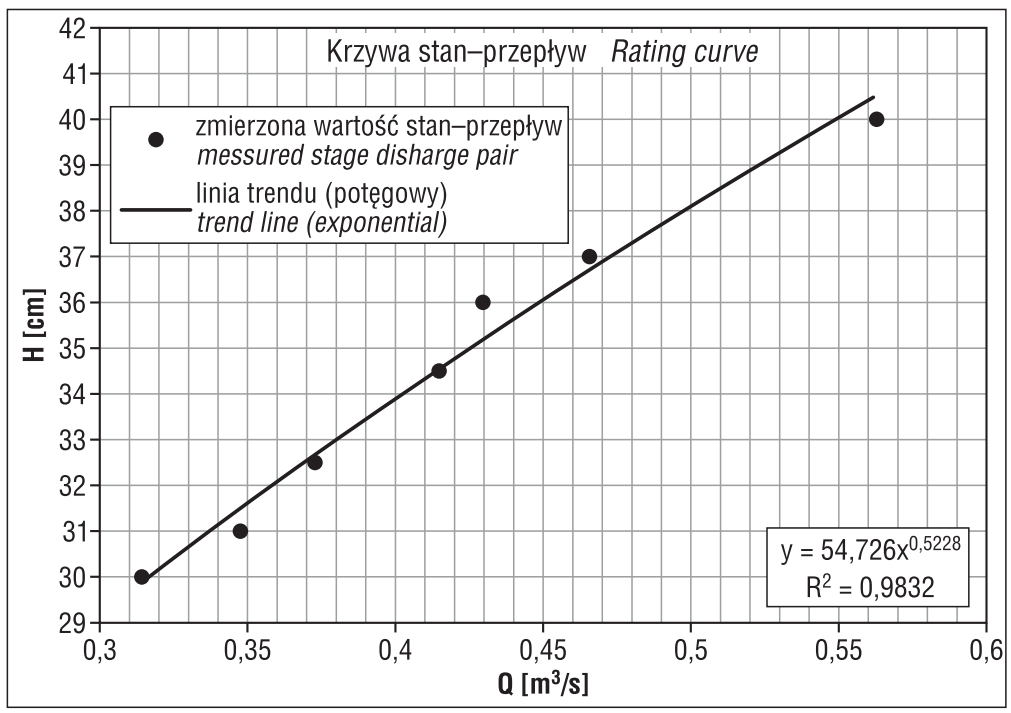

W kanale pomiarowym zaznaczał się okresowy, intensywny dopływ wód z sąsiedniego obszaru górniczego Sieroszowice, obserwowany niekiedy kilka razy w ciągu dnia. Dopływ ten miał rytm impulsowy i był ręcznie sterowany poprzez opróżnianie zbiorników retencyjnych przy komorze pomp rejonu PZ.

W celu uzyskania informacji o wielkości dopływu wód ze zlewni PZ, trzeba było określić i odjąć wielkość dopływu z obszaru Sieroszowice. W związku z tym podczas kontrolowanego zrzutu wód z Sieroszowic przeprowadzono szczegółowe obserwacje fali wezbraniowej, które dopro-

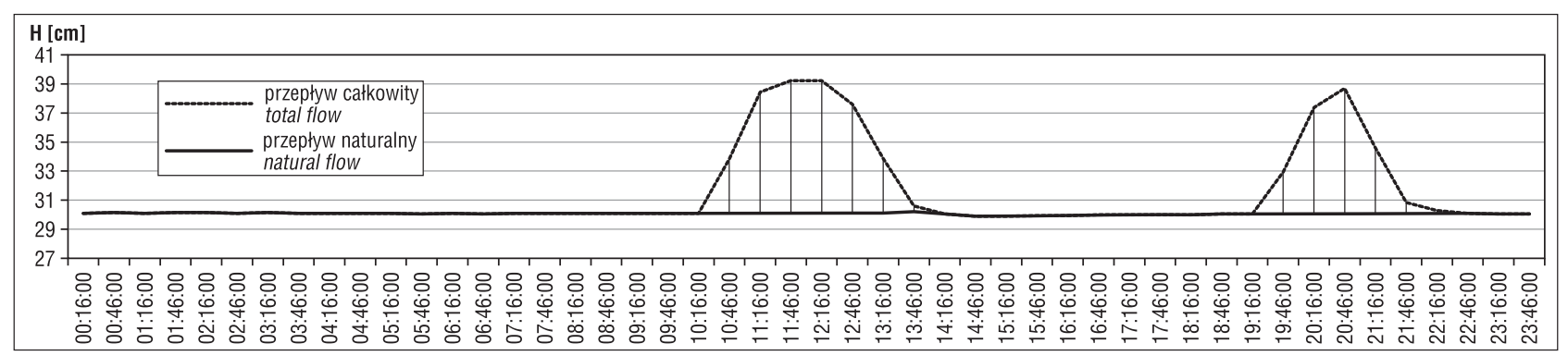

Ryc. 6. Wpływ zrzutów wody z obszaru górniczego Sieroszowice na stan wody w kanale pomiarowym ujmującym dopływ z rejonu

Polkowice Zachód - określony w dniu 11.02.2016 r.

Fig. 6. Influence of discharge from the Sieroszowice mining area into the measuring channel vs. natural groundwater inflow from the Polkowice Zachód District on Feb. 11 of 2016 
wadziły do dokładnego wyznaczenia natężenia przepływu wód w tym czasie oraz uzyskania informacji, w jaki sposób zrzut wód z Sieroszowic zaznacza się w przebiegu krzywej stanów wód w kanale pomiarowym (ryc. 6).

\section{WYNIKI BADAŃ}

W dniach od 20.01 do 19.05.2016 r. średni dopływ wód ze zlewni Polkowice Zachód do obszaru górniczego Polkowice wynosił $21,17 \mathrm{~m}^{3} / \mathrm{min}$ (tab. 2). Współczynnik zmienności dopływu wód z PZ był niewielki - wynosił 1,72\%. Całkowity średni dobowy przepływ wód przez kanał, liczony łącznie ze zrzutami wody z OG Sieroszowice, osiągnął objętość $22,27 \mathrm{~m}^{3} / \mathrm{min}$. Średnia dobowa wydajność dopływu wód z Sieroszowic wynosiła $1,101 \mathrm{~m}^{3} / \mathrm{min}$. Maksymalny dopływ wód z Sieroszowic, zarejestrowany przez limnimetr, osiagnął $3,13 \mathrm{~m}^{3} / \mathrm{min}$.

Krzywa stan-przepływ (ryc. 5.), odzwierciedlająca zależność stanu zwierciadła wody w kanale pomiarowym od natężenia przepływu wód, obserwowana w jednodniowej rozdzielczości, cechuje się wysokim współczynnikiem determinacji $\mathrm{R}^{2}=0,98$. Na jej podstawie skonstruowano krzywą dopływu z rejonu PZ (ryc. 7) oraz wyznaczono wielkość dopływu wód z Sieroszowic (tab. 2). Zważywszy na specyfikę przepływu i reżim, w jakim dokonywano zrzutów wody z rejonowej komory pomp, nie dziwi fakt, że dopływ wód z Sieroszowic cechuje się największym odchyleniem standardowym $\left(0,52 \mathrm{~m}^{3} / \mathrm{min}\right)$.

Wyniki pomiarów przepływów wód w kanale ujmującym wody ze zlewni PZ (tab. 3), realizowanych od stycznia do maja 2016 r. porównano z rezultatami badań prowadzonych w tym samym czasie przez służbę hydrogeologiczną Kopalni Polkowice-Sieroszowice (tab. 4), w ramach których wykonuje się m.in.:

1) pomiar wydajności dopływów wód do wyrobisk poziomych, z podziałem na pola/piętra na obszarze złoża Polkowice w roku 2016;

2) pomiar sumy dopływów z wycieków i otworów drenażowych na obszarze zlewni Kopalni Polkowice-Sieroszowice - zestawienie roczne;

3) oraz dane bilansowe systemu odwodnienia złoża Polkowice, uwzględniające wielkość dopływu wód z i do sąsiednich obszarów górniczych.

Po porównaniu danych dotyczących wielkości dopływu wód z Sieroszowic stwierdzono, że występują duże różnice pomiędzy wynikami badań własnych a rezultatami pomiarów prowadzonych przez służbę hydrogeologiczną Kopalni Polkowice-Sieroszowice. Średnio wyniki te różnią się o ok. $0,52 \mathrm{~m}^{3} / \mathrm{min}$, czyli aż o $34 \%$ (tab. 5). Współczynnik zmienności obliczony na podstawie

Tab. 2. Średni przepływ w kanale pomiarowym ujmującym wody z obszaru górniczego Polkowice Zachód w okresie 20.01-19.05.2016 r. oraz podstawowe parametry statystyczne tego przepływu (w rozdzielczości jednodniowej)

Table 2. Average results of discharge rates into the measuring channel during 20.01-19.05.2016 with statistical basic parameters (for one-day resolution)

\begin{tabular}{|c|c|c|c|c|c|c|}
\hline \multirow[t]{2}{*}{$\begin{array}{l}\text { Dopływ wody } \\
\text { Water discharge }\end{array}$} & \multirow{2}{*}{$\begin{array}{c}\text { Średni } \\
\text { Average }\end{array}$} & \multirow{2}{*}{$\begin{array}{c}\text { Maksymalny } \\
\text { Maximal }\end{array}$} & \multirow{2}{*}{$\begin{array}{c}\begin{array}{c}\text { Minimalny } \\
\text { Minimal }\end{array} \\
{\left[\mathrm{m}^{3} / \mathrm{min}\right]}\end{array}$} & \multirow{2}{*}{$\begin{array}{c}\text { Odchylenie } \\
\text { standardowe } \\
\begin{array}{c}\text { Standard } \\
\text { deviation }\end{array} \\
{\left[\mathrm{m}^{3}\right]}\end{array}$} & \multicolumn{2}{|c|}{$\begin{array}{c}\text { Współczynnik } \\
\text { zmienności dopływu wód } \\
\text { Coefficient } \\
\text { of variation inflow }\end{array}$} \\
\hline & & & & & & {$[\%]$} \\
\hline $\begin{array}{l}\text { Całkowity } \\
\text { Total }\end{array}$ & 22,270 & 24,331 & 20,856 & 0,570 & 0,026 & 2,56 \\
\hline $\begin{array}{l}\mathrm{Z} \text { rejonu } \mathrm{PZ} \\
\text { From } \mathrm{PZ} \text { district }\end{array}$ & 21,170 & 21,851 & 19,975 & 0,365 & 0,017 & 1,72 \\
\hline $\begin{array}{l}\text { Z rejonu Sieroszowic } \\
\text { From Sieroszowice district }\end{array}$ & 1,101 & 3,132 & 0,082 & 0,522 & 0,474 & 47,37 \\
\hline
\end{tabular}

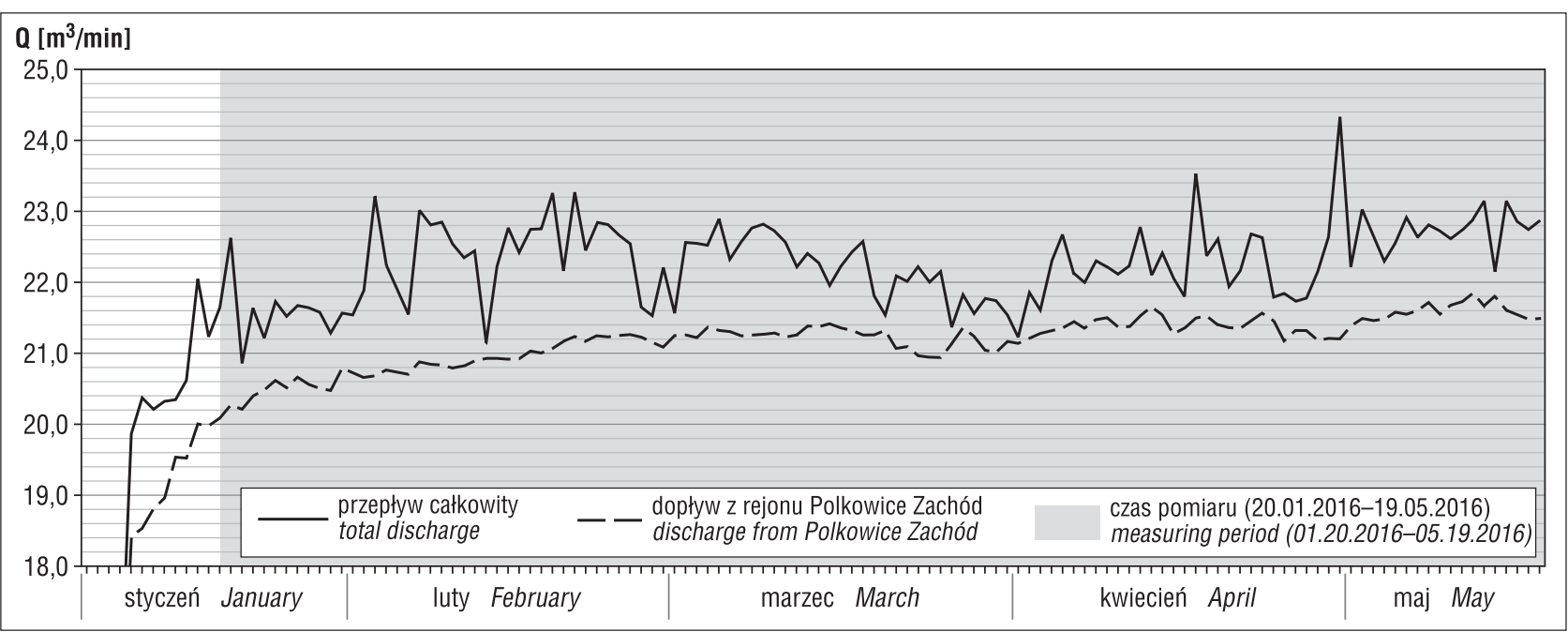

Ryc. 7. Dopływ całkowity, zmierzonyw kanale pomiarowym i wyznaczony dopływ z rejonu Polkowice Zachód

Fig. 7. Total inflow in the measuring channel and calculated inflow from the Polkowice Zachód district 
pomiarów własnych (30\%) jest niemal dwukrotnie większy (tab. 5) od wynikającego z danych kopalni (15,9\%). Mimo istotnych różnic w ocenie wielkości dopływu wód do obszarów górniczych LGOM obserwuje się zachowanie ogólnych trendów zmian wielkości dopływu np. współczynnik zmienności przepływu w kanale ujmującym wody zlewni technologicznej PZ (1,72\% - tab. 2), obliczony dla interwału dobowego $\mathrm{w}$ okresie badań, jest prawie taki sam jak współczynnik zmienności dla sumy dopływów z OG Polkowice i OG Radwanice Wschód (1,74\% - tab. 4), rozpatrywanych w interwale miesięcznym.

\section{PODSUMOWANIE I PROPOZYCJA MODYFIKACJI SIECI POMIAROWEJ DOPLYWÓW WÓD DO LGOM}

Wyniki badań wskazują na możliwość i zasadność wykorzystania pojemnościowego rejestratora zmian wysokości zwierciadła wody (limnimetru) do pomiarów dopływów wód do wyrobisk górniczych LGOM. Na podstawie rezultatów pomiarów przepływu wód w kanale ujmującym wody zlewni Polkowice Zachód z dużą dokładnością wyznaczono zależność stanu wód w kanale od wielkości ich przepływu, cechującą się wysokim współczynnikiem determinacji. Sprzęt rejestrujący, zastosowany do badań, umożliwił pozyskanie danych w sposób ciągły, z dużą częstotliwością, w zadowalającej rozdzielczości i bez znacznych nakładów finansowych, jednak przystosowanie systemu odwadniania do tego typu pomiarów jest kosztowne.

Niestety, dane uzyskane podczas badań prowadzonych w krótkim (4-miesięcznym) okresie, ale za to z dużą częstotliwością (co pół godziny) są w dużej mierze rozbieżne $\mathrm{z}$ wynikami wieloletnich pomiarów prowadzonych raz w miesiącu przez służbę hydrogeologiczną Kopalni Polkowice-Sieroszowice. Wnioskowanie na podstawie porównania tych danych jest wysoce utrudnione.

Miesięczne zestawienia wydajności dopływów wód podziemnych, prowadzone przez służby hydrogeologiczne kopalni, umożliwiają odnotowanie epizodycznych wzrostów wielkości dopływu wód do złoża, spowodowanych nacięciem przez front eksploatacji silniej zawodnionych stref złoża, takich jak szczeliny i pustki krasowe, jednak w rocznych zestawieniach zapis takich wydarzeń staje się niewidoczny, co zauważają specjaliści zajmujący się badaniem warunków hydrogeologicznych na terenie kopalń LGOM (Fiszer, Kalisz, 2007; Stochel i in., 2014). Uwidacznia się także zasadność analizy otrzymanych danych w odniesieniu do zjawisk hydrogeologicznych obserwowanych w wyrobiskach górniczych w okresie
Tab. 3. Dopływ wód do obszaru górniczego Polkowice (porównanie wyników badań autora, prowadzonych od stycznia do maja 2016 r. z danymi kopalni (2016 - Bilans, 2016)

Table 3. Inflow rates into the Polkowice mining area (results derived from the author's study conducted from January to May of 2016 vs. 2016-mine data - Bilans, 2016)

\begin{tabular}{|c|c|c|c|}
\hline \multirow{2}{*}{$\begin{array}{l}\text { Okres pomiarowy } \\
\text { Measuring period }\end{array}$} & \multicolumn{3}{|c|}{$\begin{array}{l}\text { Średni przeplyw wód w kanale (pomiary wlasne) } \\
\text { Average discharge in channel (based on own measurements) } \\
{\left[\mathrm{m}^{3} / \mathrm{min}\right]}\end{array}$} \\
\hline & \begin{tabular}{|c|} 
z rejonu \\
Polkowice Zachód \\
from \\
Polkowice West district
\end{tabular} & $\begin{array}{l}\text { całkowity } \\
\text { total }\end{array}$ & $\begin{array}{l}\text { z rejonu Sieroszowic } \\
\text { from } \\
\text { Sieroszowice district }\end{array}$ \\
\hline Styczeń / January & 20,398 & 21,553 & 1,155 \\
\hline Luty / February & 20,961 & 22,385 & 1,419 \\
\hline Marzec / March & 21,229 & 22,203 & 0,971 \\
\hline Kwiecień / April & 21,373 & 22,175 & 0,797 \\
\hline Maj / Mai & 21,574 & 22,805 & 1,236 \\
\hline \multicolumn{4}{|c|}{$\begin{array}{l}\text { Średnia na podstawie pomiarów wlasnych } \\
\text { Average based on own measurements }\end{array}$} \\
\hline $\begin{array}{l}\text { 20.01-19.05.2016 } \\
\text { 20 January-19 Mai } 2016\end{array}$ & 21,170 & 22,270 & 1,101 \\
\hline $\begin{array}{l}\text { Luty-kwiecień } \\
\text { February-April }\end{array}$ & 21,188 & 22,254 & 1,062 \\
\hline
\end{tabular}

Średnia na podstawie pomiarów wydajności dopływów do wyrobisk górniczych Average based on measuring session inflow efficiency to mine excavations

\begin{tabular}{l|c|c|c}
\hline I półrocze / I half year & 19,858 & - & - \\
\hline II półrocze / II half year & 18,775 & - & - \\
\hline Rok 2016 / 2016 Year & 19,317 & - & - \\
\hline
\end{tabular}

Średnia na podstawie danych statystycznych kopalni

Average based on statistical data from mine

\begin{tabular}{l|l} 
Rok 2016 & 19,739 \\
2016 Year
\end{tabular}

\begin{tabular}{|l|c|c|c|}
\hline \multicolumn{4}{|c|}{$\begin{array}{c}\text { Odchylenie standardowe (w interwale miesięcznym) } \\
\text { Standard deviation (in one month interval) }\end{array}$} \\
\hline $\begin{array}{l}\text { Rok 2016 } \\
\text { 2016 Year }\end{array}$ & 0,455 & 0,452 & 0,240 \\
\hline $\begin{array}{l}\text { Luty-kwiecień } \\
\text { February-April }\end{array}$ & 0,209 & 0,114 & 0,321 \\
\hline
\end{tabular}

Wspólczynnik zmienności (w interwale miesięcznym) Coefficient of variation (in one month interval)

\begin{tabular}{|l|c|c|c|}
\hline $\begin{array}{l}\text { Rok } 2016 \\
2016 \text { Year }\end{array}$ & $2,15 \%$ & $2,03 \%$ & $21,80 \%$ \\
\hline $\begin{array}{l}\text { Luty-kwiecień } \\
\text { February-April }\end{array}$ & $0,99 \%$ & $0,51 \%$ & $30,21 \%$ \\
\hline
\end{tabular}

pomiarowym, z tym że zagadnienie to wykracza poza zakres tematyczny niniejszej pracy.

Jeśli chodzi o koncepcję monitoringu natężenia dopływów wód podziemnych do wyrobisk górniczych OG Polkowice to powinna się ona opierać na zespole co najmniej kilku urządzeń rejestrujących wielkość tego dopływu. Ich rozmieszczenie powinno umożliwiać pomiar natężenia dopływu wód $\mathrm{z}$ wyrobisk górniczych w miejscach newralgicznych dla robót eksploatacyjnych (wskazanych przez służby hydrogeologiczne kopalni) oraz w miarę możliwości przy ujściach poszczególnych zlewni technologicznych. 
Tab. 4. Dopływ wód do obszarów górniczych Polkowice i Radwanice Wschód w 2016 r. (Bilans, 2016)

Table 4. Inflow rates into the Polkowice and Radwanice Wschód mining areas in 2016 (Bilans, 2016)

\begin{tabular}{|c|c|c|c|c|}
\hline \multirow[b]{2}{*}{$\begin{array}{l}\text { Okres pomiarowy w } 2016 \mathrm{r} \text {. } \\
\text { Measuring period in } 2016\end{array}$} & \multicolumn{4}{|c|}{$\begin{array}{l}\text { Doplyw wód do obszaru górniczego Polkowice } \\
\text { Inflow rates into the Polkowice mining area }\end{array}$} \\
\hline & $\begin{array}{c}\text { z OG Sieroszowice } \\
\text { from Sieroszowice } \\
\text { mining district } \\
{\left[\mathrm{m}^{3} / \mathrm{min}\right]}\end{array}$ & $\begin{array}{c}\text { z OG Polkowice } \\
\text { from Polkowice mining area } \\
{\left[\mathrm{m}^{3} / \mathrm{min}\right]}\end{array}$ & $\begin{array}{c}\text { z OG Radwanice Wschód } \\
\text { from Radwanice Wschodnie } \\
\text { mining area } \\
{\left[\mathrm{m}^{3} / \mathrm{min}\right]}\end{array}$ & $\begin{array}{c}\text { z OG Polkowice } \\
\text { + OG Radwanice Wschód } \\
\text { from Polkowice } \\
\text { + Radwanice Wschodnie } \\
\text { mining areas } \\
{\left[\mathrm{m}^{3} / \mathrm{min}\right]}\end{array}$ \\
\hline Styczeń 2016 / January & 1,322 & 25,129 & 0,015 & 25,144 \\
\hline Luty / February & 1,866 & 24,359 & 0,015 & 24,374 \\
\hline Marzec / March & 1,523 & 23,625 & 0,010 & 23,635 \\
\hline Kwiecień / April & 1,373 & 23,662 & 0,010 & 23,672 \\
\hline Maj / May & 1,528 & 23,510 & 0,010 & 23,520 \\
\hline Czerwiec / June & 1,841 & 23,263 & 0,010 & 23,273 \\
\hline Lipiec / July & 1,883 & 23,013 & 0,010 & 23,023 \\
\hline Sierpień / August & 1,561 & 22,470 & 0,010 & 22,480 \\
\hline Wrzesień / September & 1,275 & 22,587 & 0,010 & 22,597 \\
\hline Październik / October & 1,148 & 24,019 & 0,010 & 24,029 \\
\hline Listopad / November & 1,138 & 23,370 & 0,010 & 23,380 \\
\hline Grudzień / December & 1,778 & 23,462 & 0,010 & 23,472 \\
\hline I półrocze / I half year & 1,572 & 23,925 & 0,012 & 23,937 \\
\hline II półrocze / II half year & 1,467 & 23,156 & 0,010 & 23,166 \\
\hline $\begin{array}{l}\text { Średnia w } 2016 \mathrm{r} . \\
\text { Average in } 2016\end{array}$ & 1,520 & 23,539 & 0,011 & 23,550 \\
\hline $\begin{array}{l}\text { Średnia luty-kwiecień } 2016 \\
\text { Average February-April, } 2016\end{array}$ & 1,587 & 23,882 & 0,012 & 23,894 \\
\hline \multicolumn{5}{|c|}{$\begin{array}{l}\text { Odchylenie standardowe (w interwale miesięcznym) } \\
\text { Standard deviation (in one month interval) }\end{array}$} \\
\hline Rok 2016 / 2016 Year & 0,274 & 0,732 & 0,002 & 0,733 \\
\hline $\begin{array}{l}\text { Luty-kwiecień } 2016 \\
\text { February-April, } 2016\end{array}$ & 0,253 & 0,414 & 0,003 & 0,417 \\
\hline \multicolumn{5}{|c|}{$\begin{array}{c}\text { Wspólczynnik zmienności (w interwale miesięcznym) } \\
\text { Coefficient of variation (in one month interval) }\end{array}$} \\
\hline Rok 2016 / 2016 Year & $18,05 \%$ & $3,11 \%$ & $17,75 \%$ & $3,11 \%$ \\
\hline
\end{tabular}

Tab. 5. Zrzut wody z obszaru górniczego Sieroszowice

Table 5. Discharge rate from Sieroszowice mining area

\begin{tabular}{|c|c|c|c|c|}
\hline \multirow{2}{*}{$\begin{array}{l}\text { Okres pomiarowy } \mathrm{w} 2016 \mathrm{r} \text {. } \\
\text { Measuring period in } 2016\end{array}$} & \multicolumn{2}{|c|}{$\begin{array}{l}\text { Dopływ wód z Sieroszowic }\left[\mathrm{m}^{3} / \mathrm{min}\right] \\
\text { Discharge of water from Sieroszowice }\left[\mathrm{m}^{3} / \mathrm{min}\right]\end{array}$} & \multicolumn{2}{|c|}{$\begin{array}{c}\text { Różnica } \\
\text { Difference }\end{array}$} \\
\hline & \begin{tabular}{|l|} 
wg danych kopalni (Bilans, 2016) \\
based on mine data (Bilans, 2016)
\end{tabular} & $\begin{array}{l}\text { na podstawie pomiarów wlasnych } \\
\text { based on own measurements }\end{array}$ & {$\left[\mathrm{m}^{3} / \mathrm{min}\right]$} & $\%$ \\
\hline Luty / February & 1,866 & 1,419 & 0,447 & 24 \\
\hline Marzec / March & 1,523 & 0,971 & 0,552 & 36 \\
\hline Kwiecień / April & 1,373 & 0,797 & 0,576 & 42 \\
\hline Średnia / Average & 1,587 & 1,062 & 0,525 & 34 \\
\hline \multicolumn{5}{|c|}{ Odchylenie standardowe / Standard deviation } \\
\hline Luty-kwiecień / February-April & 0,252 & 0,321 & & \\
\hline \multicolumn{5}{|c|}{ Wspólczynnik zmienności / Coefficient of variation } \\
\hline Luty-kwiecień / February-April & 15,905 & 30,002 & & \\
\hline
\end{tabular}

Do rejestracji zmian natężenia przepływu można wykorzystać stosowane $\mathrm{w}$ praktyce hydrogeologicznej kopalni przelewy miernicze (Rogoż, 2004). Pomiar taki polega na rejestracji zmian wysokości wód przed przelewem pomia- rowym za pomocą limnimetru pojemnościowego bądź pływaka, sprzężonego z urządzeniem rejestrującym jego położenie w odniesieniu do wyznaczonej empirycznie zależności stan-przepływ. 
Analizując wyniki pomiarów, należy uwzględniać i rejestrować ścieżki redystrybucji wód oraz ich wpływ na otrzymane dane oraz sytuację hydrogeologiczną w wyrobiskach. O istotnej roli procesu redystrybucji może świadczyć fakt, iż wyznaczona w toku badań zmienność dopływu wód $\mathrm{w}$ interwale dobowym $(\sim 1,72 \%)$ odpowiadała współczynnikowi zmienności wyznaczonemu dla sumy dopływów z OG Polkowice i Radwanice Wschód w interwale miesięcznym (w okresie luty-kwiecień).

Baza danych pochodzacych $\mathrm{z}$ sieci pomiarowej powinna być na bieżąco aktualizowana i uzupełniana danymi dotyczącymi oceny wpływu działalności górniczej kopalni na warunki hydrogeologiczne w sąsiednich obszarach górniczych.

Sieć pomiarowa, zaprojektowana według opisanych wskazówek, stanowiłaby cenne źródło informacji, ponieważ umożliwiałaby śledzenie dzień po dniu kształtowania się warunków hydrogeologicznych kopalni w odpowiedzi na postęp eksploatacji złoża. Uruchomienie takiego systemu w obszarze górniczym Polkowice usprawniłoby proces bilansowania wielkości dopływów, który z powodzeniem mógłby być rozwijany w pozostałych kopalniach LGOM. Poprawność działania takiej sieci pomiarowej można sprawdzić jedynie za pomocą porównania do wyników kartowania hydrogeologicznego wydajności dopływów do złoża, wobec czego przeprowadzanie pomiarów tylko dwa razy do roku wydaje się niewystarczające. Proponuje się zatem wykonywanie pomiarów dopływów wód do złoża raz na kwartał, jak to już wcześniej praktykowano w Kopalni Polkowice-Sieroszowice.

Ostateczny kształt zaprojektowanej sieci pomiarowej $\mathrm{w}$ dużym stopniu zależy od technicznych możliwości instalacji urządzeń rejestrujących w wyrobiskach górniczych. Zaproponowane rozwiązania mogą znacząco ułatwić skonstruowanie sieci pomiarowej dopływu wód do wyrobisk kopalni. Co pozwoli nie tylko przyspieszyć wdrożenie takiego systemu, ale i znacząco obniżyć jego koszty w początkowym stadium funkcjonowania.

Warto też zwrócić uwagę na szybki rozwój innych metod pomiaru przepływów wód w otwartych kanałach przepływowych, np. z zastosowaniem urządzeń ultradźwiękowych, optycznych czy elektromagnetycznych, które nie tylko zapewniają dużą dokładność pomiarów, ale i często nie wymagają okresowej kalibracji (Michalski i in., 2006).

Autor serdecznie dziękuje Dr. M. Wcisło oraz Hydrogeologom pracującym w ZG Polkowice-Sieroszowice za pomoc, cenne uwagi i wskazówki. Podziękowania należą się również Recenzentom, którzy w istotny sposób przyczynili się do ostatecznej formy artykułu, a w szczególności Prof. P. Bukowskiemu za cenne uwagi w końcowej fazie redakcji artykułu. Informacje zawarte w niniejszym artykule pozyskano $\mathrm{w}$ ramach pisania pracy dyplomowej (Błachowicz, 2017) za zgodą KGHM Polska Miedź S.A.

\section{LITERATURA}

BAJKIEWICZ-GRABOWSKA E., MAGNUSZEWSKI A., MIKULSKI Z. 1993 - Hydrometria, Wyd. Nauk. PWN, Warszawa: 101-126.

BANASZAK A., BANAŚ M. 1996-Geologia. Cz. II. [ W:] Piestrzyński A., Zaleska-Kuczmierczyk M. (red.), Monografia KGHM Polska Miedź SA, Wyd. CBPM Cuprum Sp. z o.o., Lubin.

BANASZAK A., BANAŚ M. 2007 - Geologia. Cz. II. [W:] Piestrzyński A., Banaszak A., Zaleska-Kuczmierczyk M. (red.), Monografia KGHM Polska Miedź SA, Wyd. CBPM Cuprum Sp. z o.o., Lubin.

BECKER R., MARKIEWICZ A., KALISZ M., KRZYWAŃSKI Z., SZUMILAS S., WŁOCH A. 2006 - Charakter kontaktów między poziomami wodonośnymi w obszarze miedzionośnym południowej części monokliny przedsudeckiej w aspekcie oceny zagrożeń wodnych kopalń KGHM Polska Miedź SA, Warsztaty z cyklu: Zagrożenia naturalne w górnictwie.

BECKER R., FISZER J., KALISZ M. 2007 - Geologia. Cz. II. Hydrogeologia. [W:] Piestrzyński A., Banaszak A., Zaleska-Kuczmierczyk M. (red.), Monografia KGHM Polska Miedź SA, Wyd. CBPM Cuprum Sp. z o.o., Lubin: 82-88.

BILANS wód kopalnianych O/ZG P-S - 2016. Arch. ZG Polkowice-Sieroszowice.

BŁACHOWICZ M. 2017 - Dynamika drenażu głębokich poziomów wodonośnych złoża Polkowice. Pr. magist., Arch. Uniw. Wroc.

BOCHEŃSKA T. 1988 - Kształtowanie się warunków hydrogeologicznych w lubińsko-głogowskim obszarze miedzionośnym pod wpływem odwadniania kopalń. Acta Univ. Wratisl., 964, Pr. Geol.-Miner., 11, 2: 127-141. BOCHEŃSKA T. 2003 - Hydrogeologia złóż i problemy wodne górnictwa rud miedzi: Warunki hydrogeologiczne. [W:] Wilk Z. i Bocheńska T. (red.). Hydrogeologia polskich złóż kopalin i problemy wodne górnictwa, t. 2, Wyd. Nauk.-Dydakt. AGH, Kraków.

BOCHEŃSKA T., FISZER J., KALISZ M. 2000 - Prognosis of Groundwater Inflow into the Copper Mines in the Lubin-Glogow Region. Environment. Geol., 39 (6): 587-594.

BOCHEŃSKA T., KALISZ M. 2001 - Warunki hydrodynamiczne w strefie wychodni cechsztynu w rejonie kopalń rud miedzi Lubin i Polkowice - stan na 2000 r. Mat. Symp. Współ. Prob. Hydrogeol., Wrocław-Krzyżowa: 297-306.

CHUDY K., WORSA-KOZAK M., PIKUŁA M. 2017 - Rozwój metod rozpoznania warunków hydrogeologicznych na potrzeby wykonywania pionowych wyrobisk udostępniających złoże - przykład LGOM. Prz. Geol., 65 (11/1): 1035-1043.

DYJOR S. 1978 - Wykształcenie i stratygrafia utworów trzeciorzędowych na obszarze Legnicko-Głogowskiego Okręgu Miedziowego. [W:] Przewodnik 50 Zjazdu Polskiego Towarzystwa Geologicznego, Warszawa: $210-214$.

FISZER J., KALISZ M. 2007 - Weryfikacja prognoz dopływów wód podziemnych do kopalń KGHM Polska Miedź S.A na lata 2008-2015, Cuprum, 2 (43): 9-25.

KŁAPCIŃSKI J. 1971 - Litologia, fauna, stratygrafia i paleogeografia permu monokliny przedsudeckiej. Geol. Sudet., 5: 1-135.

KŁAPCIŃSKI J., PERYT T.M. 2007 - Budowa geologiczna monokliny przedsudeckiej. [W:] Piestrzyński A., Banaszak A., Zaleska- Kuczmierczyk M. (red.), Monografia KGHM Polska Miedź SA., Część II Geologia, Wyd. CBPM Cuprum Sp. z o.o., Lubin: 69-77.

KWAŚNY L., KALISZ M. 2011 - Dodatek do dokumentacji geologicznej złoża rud miedzi Polkowice w kat. B + C1. Arch. KGHM Cuprum Sp. z o.o. CBR, Wrocław.

MICHALSKI A., SIENKIEWICZ J., WATRAL Z. 2006 - Metody pomiaru przepływu na małych otwartych kanałach przepływowych. Diagnostyka, 3 (39): 269-278.

REJESTR pomiarów dopływu wody do wyrobisk górniczych - 2000-2016. Arch. ZG Polkowice-Sieroszowice.

ROGOŻ M. 2004 - Hydrogeologia kopalniana z podstawami hydrogeologii ogólnej. Główny Instytut Górnictwa, Katowice.

ROZPORZADDZENIE Ministra Gospodarki z dnia 28 czerwca 2002 r. w sprawie bezpieczeństwa i higieny pracy, prowadzenia ruchu oraz specjalistycznego zabezpieczenia przeciwpożarowego $\mathrm{w}$ podziemnych zakładach górniczych (z późniejszymi zmianami) - Dz.U. 2002 nr 139 poz. 1169.

ROZPORZADZENIE Ministra Energii z dnia 23 listopada 2016 r. w sprawie szczegółowych wymagań dotyczących prowadzenia ruchu podziemnych zakładów górniczych - Dz.U. 2017 poz. 1118.

STAŚKO S., GURWIN J., WCISŁO M., MODELSKA M., KRYZA H., KRYZA J., OLICHWER T, BUCZYŃSKI S., TARKA R., WAૃSIK M., BECKER R. 2012 - Model koncepcyjny systemu hydrogeologicznego obszaru oddziaływania Lubińsko-Głogowskiego Obszaru Miedzionośnego (LGOM). Biul. Państw. Inst. Geol., 451: 203-210.

STOCHEL B., CHUDY K. (red.) 2014 - Dokumentacja hydrogeologiczna określająca warunki hydrogeologiczne w związku z zamierzonym wykonywaniem odwodnienia w celu wydobywania rud miedzi ze złoża Polkowice. Arch. KGHM Cuprum sp. z o.o., Wrocław.

SZTELAK J. 1968 - Rodzaje zagrożeń wodnych w kopalniach rejonu monokliny przedsudeckiej ze szczególnym uwzględnieniem zagrożeń serii węglanowej oraz sposoby ich zwalczania. Zesz. Nauk. PŚl., 227: 547-55. WYŻYKOWSKI J. 1958 - Poszukiwanie rud miedzi na obszarze strefy przedsudeckiej. Prz. Geol., 1: 17-22.

WYŻYKOWSKI J. 1971 - Cechsztyńska formacja miedzionośna w Polsce. Prz. Geol., 3: 117-122.

Praca wpłynęła do redakcji 7.03.2018 r.

Akceptowano do druku 4.06.2018 r. 